\title{
MAS を用いた人工経済モデルによる格差社会の発生 \\ Artificial Economic Divide Society Modeled by the Multi-Agent System
}

\section{○池藤 美幸 ${ }^{1}$, 伊藤 尚 ${ }^{2}$, 前田 義信 1.3 \\ 1. 新潟大学工学部福祉人間工学科, 2. 新潟大学大学院自然科学研究科, 3. 広島大学大学院工学研究科 *Miyuki Ikefuji, Nao Ito and Yoshinobu Maeda}

1. Department of Biocybernetics, Faculty of Engineering, Niigata University

2. Graduate School of Science and Technology, Niigata University

3. Graduate School of Engineering, Hiroshima University

\section{1. はじめに}

近年，日本では「格差社会」が社会問題の一つとして注 目を集めている．格差の拡大は階層の固定化を招く恐れが あり，貧困・弱者層に対して，公平性を欠いた社会となる ことが予想される1) . 本研究ではMAS(マルチェージェン トシステム)を用いて人工的な経済社会を構築し, 経済活動 においてどのような形で格差が発生するのかを明らかにす る. 本稿では, エージェントの職業選択と価格設定行動を 通した経済モデルを構築し，エージェント間に発生する金 銭的格差について考察する.

\section{2. モデルの概要}

構築した経済モデルには， $N_{P}$ 人の生産者エージェント （以下PA）と $N_{C}$ 人の消費者エージェント（以下CA）が存在す る. 各PAはそれぞれスキルと呼ばれる能力をもち， $S$ 種類 のスキルの中から $S_{\max }$ 個を所持している.PAは $M$ 種類の職 業の中から 1 つを選択して資本を生産し，価格を設定して CAに資本を販売する。この時，PA自身が持つスキルとPA が選択した職業がもつスキルとが一致しているほど, PAの その職業に対する満足度が高くなる.CAは欲しい資本を最 も価格を安く設定しているPAから購入する.PAは資本が売 却されることで得た利益と職業に対する満足度との和の変 化によって，職業と価格をそれぞれ選択していく．

2.1 エージェントの設定

(1) PAの設定

(1) PA は異なる組み合わせで同数のスキルを所持する. 職業にも同様のスキルが存在する.

(2) PA が選択している職業に対するスキルの一致数を 「満足度」と呼ぶ.

(3) 各 PA はランダムに 1 種類の職業を選択し, 資本を 1 つ生産する.

(4) 各 PA は資本の価格を設定し, PA に購入されるこ とで, 利益を得る.

(5) 利益と「満足度」の和を PA の「モチベーション」 と呼ぶ. 各 PAは「モチベーション」の増減で職業 や価格を変更する.

(2) CA の設定

PA が生産した資本の中から，最低価格の資本をラン ダムに 1 つ選択し, 購入する.

2.2 シミュレーションの流れとエージェントの行動 シミュレーションの 1 ステップの流れは以下のように なる.

(1) PA が職業を選択.

(2) PA が資本を生産.

(3) PA が価格を設定.

(4) CA が資本を購入.

(5) PA $の$ 所持金が変化.

(6) PAの「モチベーション」が変化.
また，職業及び価格は以下のように決定される.

(1) 職業選択

各 PA は,「モチベーション」が前回以下に減少した場合 にのみランダムに職業を選択する。 それ以外の場合は職業 を固定する.

(2) 価格設定

各 PA は，資本が売れた場合には価格を 10 上げ，売れな かった場合かつ「モチベーション」が前回以下に減少した 場合に価格を 10 下げる.それ以外の場合では価格を固定す る. 価格は $0 \sim 100$ までの 10 刻みの整数で変化する.

\section{3 . 結果}

$N_{P}=20$ 人, $N_{C}=10$ 人, $S=20$ 種類, $S_{\max }=5$ 個, $M=5$ 種類, 資 本の初期価格を 10 , 所持金の初期值を 10000 として，シミュ レーションを行った. 各ステップにおける所持金のジニ係数 と資本の平均価格の推移をFig. 1 に示す. 縦軸はジ二係数及 び価格, 横軸はステップ数である.

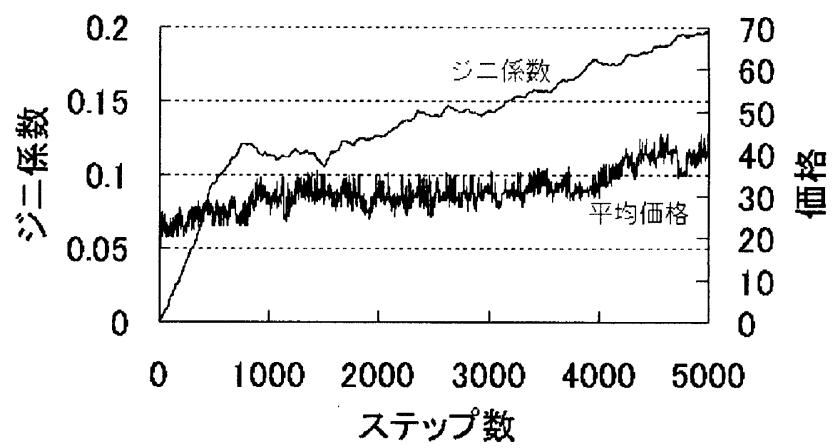

Fig.1 Transitions of Gini coefficient and mean price

\section{4. 考察}

Figure 1 より, ジニ係数 (以下に GC) はシミュレーション開 始時から 1000 ステップ付近まで急激に上昇したが, それ以降 は緩やかに上昇し続ける結果が得られた。ささらに, GC が急 激に上昇している間, 資本の平均価格も上昇傾向にあること が読み取れる.これは，平均価格の上昇過程では，資本を売 却して得られる利益に差が生じたため, PA 間で所持金の格差 が急激に上昇したと考えられる。 また，平均価格が一定とな っている間では, PA 全体が同じような額の利益を得ることが できるため, 所持金の格差の上昇が次第に緩やかになったと 考えられる.

以上のことより，資本の平均価格の変化が PA 間の所持金 の格差に影響を及ぼしていることが示唆された。

\section{5. 参考文献}

1）瀮木俊詔. 格差社会：岩波書店，2006. 